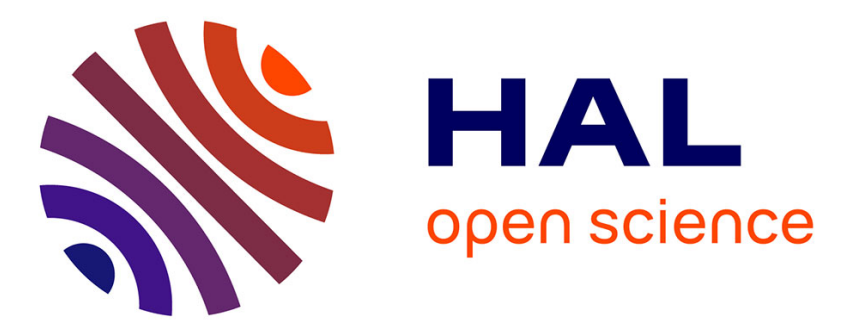

\title{
Uranium exposure of human dopaminergic cells results in low cytotoxicity, accumulation within sub-cytoplasmic regions, and down regulation of MAO-B
}

\author{
A. Carmona, Veronique Malard, E. Avazeri, S. Roudeau, F. Porcaro, E. \\ Paredes, C. Vidaud, C. Bresson, R. Ortega
}

\section{To cite this version:}

A. Carmona, Veronique Malard, E. Avazeri, S. Roudeau, F. Porcaro, et al.. Uranium exposure of human dopaminergic cells results in low cytotoxicity, accumulation within sub-cytoplasmic regions, and down regulation of MAO-B. NeuroToxicology, 2018, 68, pp.177-188. 10.1016/j.neuro.2018.07.019 . cea-02339669

\section{HAL Id: cea-02339669 https://hal-cea.archives-ouvertes.fr/cea-02339669}

Submitted on 4 Nov 2019

HAL is a multi-disciplinary open access archive for the deposit and dissemination of scientific research documents, whether they are published or not. The documents may come from teaching and research institutions in France or abroad, or from public or private research centers.
L'archive ouverte pluridisciplinaire HAL, est destinée au dépôt et à la diffusion de documents scientifiques de niveau recherche, publiés ou non, émanant des établissements d'enseignement et de recherche français ou étrangers, des laboratoires publics ou privés. 


\title{
Uranium exposure of human dopaminergic cells results in low cytotoxicity, accumulation within sub- cytoplasmic regions, and down regulation of MAO-B gene expression
}

\author{
Asuncion Carmona, Véronique Malard, Emilie Avazeri, Stéphane Roudeau, \\ Francesco Porcaro, Eduardo Paredes, Claude Vidaud, Carole Bresson, Richard \\ Ortega
}

Revue: Neurotoxicology

Potential Reviewers: Aschner; Homma Takeda, Bussy, Dinocourt

HIGHLIGHTS

- Natural uranium is cytotoxic towards dopaminergic cells but only at high concentration, not relevant for human exposure

- Uranium limited cytotoxicity is related to its low intracellular accumulation

- Uranium is located in defined cytoplasmic regions suggesting its accumulation within cell organelles yet to be determined

- Monoamine oxidase B gene expression is decreased following natural uranium exposure even at non cytotoxic exposure levels.

\section{ABSTRACT}

Natural uranium is an ubiquitous element present in the environment and human exposure to low levels of uranium is unavoidable. Although the main target of acute uranium toxicity is the kidney, some concerns have been recently raised about the effect chronic exposure to low levels of uranium on neurological functions. Studies of uranium neurotoxicity on animal models have shown subtle changes of behavior such as increased locomotor activity, perturbation of the sleep-wake cycle, decreased memory, and increased anxiety. Only very few studies have addressed the molecular mechanisms of uranium neurotoxicity indicating that the cholinergic and dopaminergic systems could be altered. The main objective of this study was to investigate the mechanisms of uranium toxicity on human SH-SY5Y differentiated into a dopaminergic phenotype as verified by tyrosine hydroxylase expression. SH-SY5Y differentiated cells were exposed to 1, 10, 125 and $250 \mu \mathrm{M}$ of natural uranium. 
First the cytotoxicity of uranium was evaluated using ATP fluorescence assays. Our results show that uranium cytotoxicity only occurs at relatively high exposure concentrations (>125 $\mu \mathrm{M})$, far from the expected values for uranium in the blood even after occupational exposure $(<1 \mu \mathrm{M})$. Then uranium quantitative subcellular distribution was investigated by means of micro-PIXE (Particle Induced X-ray Emission). The subcellular element imaging revealed that uranium was present in defined perinuclear regions of the cytoplasm but never in the nucleus of the differentiated cells. Quantitative analysis of uranium intracellular content evidenced a very limited uranium accumulation at low levels of exposure $(1$ and $10 \mu \mathrm{M})$ and a less controlled incorporation resulting in uranium content at higher levels of exposure, when cytotoxic effects are observed (125 ad $250 \mu \mathrm{M})$. Finally the expression of genes related to the dopaminergic phenotype was determined using quantitative real time RT-PCR. The expression of monoamine oxidase B gene is statistically significantly decreased after exposure to uranium while other genes related to the dopamine system are not modified. This result together with published data indicate that the catabolism of dopamine could be a selective target for uranium neurotoxic effects.

Keywords: uranium, neurotoxicity, in vitro, subcellular distribution, dopaminergic cells, monoamine oxidase B. 


\section{Introduction}

Uranium is a natural radioelement, weakly radioactive and toxic at high concentrations for humans, whose toxicity is essentially chemical. Uranium occurs naturally in the environment, existing in nearly all rocks and soils with a typical natural abundance of 2 to $4 \mu \mathrm{g} \cdot \mathrm{g}^{-1}$. This ubiquitous presence results in continuous human exposure to low uranium concentrations mainly through ingestion (Keith et al., 2008; ATSRD, 2013). Intake from water and food approximate $0.9-1.5 \mu \mathrm{g} / \mathrm{day}$ for most of the population. Higher exposure levels may be found in geographical areas with elevated levels of naturally occurring uranium, increasing uranium content in food, or in the water especially when ground water is used for drinking. In some regions of the world, uranium in ground water can reach values most above the $30 \mu \mathrm{g} . \mathrm{L}^{-1} \mathrm{WHO}$ recommended guideline for drinking water quality (Frisbie et al., 2009; WHO, 2011). Moreover, the WHO recommended guideline for uranium in drinking water is only provisional and a matter of debate since it might not be fully protective for the general population (Frisbie et al., 2013, Ansoborlo et al., 2015). The highest human exposures are found in occupational settings, in uranium milling and processing industries, or for people working with phosphate fertilizers. Recently human exposure also involves military use of depleted uranium weapons.

In case of high uranium exposure, the main target of uranium toxicity in human are the kidneys. Less severe effects are however observed on the liver, lungs, bones, reproductive and nervous systems (Keith et al., 2008; ATSRD, 2013). In the last few years several studies have clearly pointed out that the brain is a sensitive target for uranium toxicity (reviewed in Dinocourt et al., 2015). Uranium exposure induces neurobehavioral changes such as increased locomotor activity, perturbation of the sleep-wake cycle, decreased memory, and increased anxiety on animal models. The mechanisms by which uranium induces neurological alterations are not fully known. Changes in levels of neurotransmitters and their metabolites, such as acetylcholinesterase activity and monoamine metabolism have been observed in animal brains after exposure to uranium (Bussy et al., 2006; Barber et al., 2007; Briner et al., 2008; Bensoussan et al., 2009). Further studies are needed to better understand the mechanisms of action for uranium-induced neurological effects. Such data are required to evaluate whether long-term exposure to uranium concentrations could affect neurological functions in humans especially to populations exposed to excessive uranium in the drinking water or in the food.

The aim of this study was to investigate the mechanisms of neurotoxicity of natural uranium on human dopaminergic cells. The cytotoxic concentrations were evaluated, as well as the intracellular distribution of uranium and the expression of genes involved in monoamine metabolism.

Most of the existing studies on uranium-induced toxicity involved rodent animal models and data on uranium toxicity thresholds and on molecular mechanisms of neurotoxicity in human are still scarce. Here we selected a human cell line, SH-SY5Y as study model. Human SH-SY5Y cells are frequently used as in vitro neuronal model as these cells may acquire a neuronal dopaminergic phenotype after a differentiation step (Presgraves et al., 2004). Using this cellular model we have recently evidenced the isotopic fractionation of uranium suggesting the existence of a high affinity transporter protein for uranium uptake (Paredes et al., 2016). In the present study we addressed the question of uranium intracellular distribution using Particle Induced X-ray Emission (PIXE) chemical element 
imaging. At high exposure concentrations uranium is known to form insoluble precipitates with needle shapes located in intracellular vesicles as observed with different cellular models (Carrière et al., 2006 and 2008; Pierrefite-Carle et al., 2015). Only very few studies have addressed the intracellular distribution of uranium at lower exposure concentrations before it forms precipitates. These studies have brought controversial results since in one hand, uranium was found only in the nucleus of the cells (Rouas et al. 2010; Guéguen et al., 2015), while in the other hand uranium was never found in the nucleus but in defined regions of the cytoplasm (Homma-Takeda et al., 2015). Only one study reported uranium distribution in neuron-like cells (Rouas et al., 2010). In addition, by using reverse transcriptase quantitative polymerase chain reaction (RT-qPCR) our study brings original results on the interaction of uranium with expression of genes related to the dopaminergic pathway in human cells.

\section{Material and methods}

\subsection{Reagents and solutions}

Eagle's minimum essential medium (EMEM, 30-2003; ATCC), F12 medium (21765-029; Life Technologies), FBS (30- 2020; ATCC), and penicillin/streptomycin (15070-063; Gibco-Thermo Fisher Scientific) solutions were used to prepare the culture medium for cell growing and exposure experiments. TrypLE Express 1×/EDTA (12605-010; Gibco-Thermo Fisher Scientific) was used for the trypsinization of cells. PBS ( $\mathrm{pH}$ 7.4) free of $\mathrm{CaCl}_{2}$ and $\mathrm{MgCl}_{2}$ (10010-015; Gibco) was used to wash the cells after trypsinization. Retinoic acid (RA) and 12-0-tetradecanoylphorbol-13-acetate (TPA) used for cell differentiation were purchased from Sigma-Aldrich (R2625 and P8139, respectively). A 3-mg.mL ${ }^{-1}$ RA solution was prepared in sterile dimethyl sulfoxide (DMSO, Sigma-Aldrich) under a nitrogen atmosphere in opaque tubes and stored at $-80^{\circ} \mathrm{C}$. TPA was resuspended at $1 \mathrm{mg} \cdot \mathrm{mL}^{-1}$ in sterile DMSO, and the solution was stored at $-20^{\circ} \mathrm{C}$.

\subsection{Cells and dopaminergic differentiation}

SH-SY5Y human neuroblastoma cells were purchased from ATCC USA (CRL-2266 ${ }^{\text {TM }}$, Lot 59740436). Cells were cultured according to ATCC guidelines. The complete growth medium consisted in a 1:1 mixture of Eagle's Minimum Essential Medium (EMEM, ATCC), and F12 Medium (Sigma), supplemented with $10 \%$ fetal bovine serum (FBS, ATCC), $100 \mu \mathrm{g} / \mathrm{ml}$ penicillin, $100 \mu \mathrm{g} / \mathrm{ml}$ streptomycin (Gibco). Complete growth medium was renewed every 3 to 4 days. Cells were cultured at $37^{\circ} \mathrm{C}$ in air with $5 \%$ carbon dioxide. SH-SY5Y cells were terminally differentiated into dopaminergic neuron-like cells according to the protocol of Presgraves et al. (2004), Table 1. In brief, one day after seeding at 25000 cells $\mathrm{cm}^{-2}$, cells were first treated with $10 \mu \mathrm{M}$ RA (Sigma) during 2.5 days. Then the medium was renewed using fresh complete growth medium with $80 \mathrm{nM}$ TPA (Sigma) and cells were cultured for 3.5 days. In order to control that the dopaminergic phenotype was correctly induced, the expression of tyrosine hydroxylase was evaluated by Western blot analysis.

\subsection{Western blot analysis of tyrosine hydroxylase}


Western blots were performed as described earlier \{Malard, 2009 \#524\}. After 7 days of differentiation, the cells were trypsinized, washed with PBS, then incubated with RIPA buffer (Santa Cruz) containing protease inhibitor cocktail tablet (Complete EDTA free TM Roche) and phosphatase inhibitor (Cocktail I and II, Sigma). The cellular extracts were lysed using a Dounce homogenizer (20 strokes), incubated on ice for $60 \mathrm{~min}$, and then centrifuged at 16,000 g for $60 \mathrm{~min}$. The protein content of the supernatants was determined with the Coomassie Protein Assay (Thermo Scientifc). Proteins were separated on a 4-12\% NuPAGE ${ }^{\circledR}$ Bis-Tris gel (Invitrogen) in a MOPS/SDS Running Buffer (Invitrogen) at $200 \mathrm{~V}$. Proteins from the gel were electroblotted on a $0.45 \mu \mathrm{m}$ PVDF membrane (Thermo scientific) using a semi-dry electroblot system (Biometra). After a saturation step in milk 5\%, the membrane was incubated overnight at $4^{\circ} \mathrm{C}$ in a $5 \%$ milk solution containing a polyclonal Antibody Rabbit anti-Tyrosine Hydroxylase (1/1000, cat\# AB152, Millipore). Primary antibody was then detected using an anti Rabbit HRP (1/10000, Sigma; A6154). A mouse monoclonal anti-human actin from Sigma ref $A 3854$ was used as a control at $1 / 25000$. The signals were revealed using the Western Chemiluminescent HRP Substrate from Millipore.

\subsection{Preparation of the uranium exposure solution}

In-house (Laboratoire de développement Analytique, Nucléaire, Isotopique et Elémentaire (LANIE), DEN, CEA Saclay) natural uranium oxide powder $\mathrm{U}_{3} \mathrm{O}_{8}$ was dissolved in $0.5 \mathrm{M}$ ultrapure $\mathrm{HNO}_{3}$ (SCP Science) to obtain a stock solution at $U$ concentration of $151 \mathrm{mM}$. Uranium concentration was determined by quadrupole Inductively Coupled Plasma Mass Spectrometry (ICP-MS, X7 Series; Thermo Fisher Scientific). The natural uranium stock solution was characterized by a $\delta 238$ value of $+0.66 \pm 0.12 \%$ o $(2 \sigma, n=7)$ relative to the certified $n(238 U) / n(235 U)$ of IRMM-184 material. This stock solution was diluted into a buffer, made of $0.1 \mathrm{~mol}^{-1} \mathrm{NaHCO}_{3}, 0.1 \mathrm{~mol} . \mathrm{L}^{-1} \mathrm{Na}_{2} \mathrm{CO}_{3}, 0.15 \mathrm{~mol} . \mathrm{L}^{-1} \mathrm{NaCl}$ and 0.05 mol. $\mathrm{L}^{-1}$ Tris in ultrapure water, so as to obtain an intermediate uranium solution with a $\mathrm{pH}$ compatible with cell culture experiments $(\mathrm{pH}=8-8.5)$. This dilution was performed with a ratio of 1:5 $\mathrm{v} / \mathrm{v}$ to reach a $\mathrm{U}$ concentration at $30 \mathrm{mM}$ and by drop-by-drop addition of the $\mathrm{U}$ stock solution into the buffer to avoid $U$ precipitation. Uranium was then stabilized in the intermediate solution under the tris-carbonate uranyl $(\mathrm{VI})$ complexes $\left[\mathrm{UO}_{2}\left(\mathrm{CO}_{3}\right)_{3}\right]^{4-}$, the most common uranium species found in biological fluids. $U$ concentration in the intermediate solution was daily measured by ICPMS for one week showing that the intermediate solution was stable, without any uranium precipitate, at least during 7 days. The intermediate uranium solution was prepared the day before cell exposure and stored at room temperature (Table 1 ).

\subsection{Cell exposure to uranium}

The workflow for SH-SY5Y cell culture, differentiation and uranium exposure on sample holders for micro-PIXE experiments is summarized in Table 1. Sample holders for micro-PIXE consist in a thin (2 $\mu \mathrm{m})$ ultrapure polycarbonate film stretched over a plastic frame with a $5 \mathrm{~mm} \times 5 \mathrm{~mm}$ window where cells are grown. Sample holders were sterilized in analytical grade ethanol, rinsed with ultrapure water and dried in sterile conditions. To enhance cell attachment, polycarbonate films were coated with a solution of $0.01 \mathrm{mg} \cdot \mathrm{mL}^{-1}$ bovine serum albumin, $0.01 \mathrm{mg} \cdot \mathrm{mL}^{-1}$ human fibronectin, and 0.03 $\mathrm{mg} \cdot \mathrm{mL}^{-1}$ collagen type I (all products from Sigma) prepared in complete growth medium. Before cell seeding onto polycarbonate films, SH-SY5Y cells were first cultured for 10 days after thawing, in plastic flasks following standard methods as described before. At day 0 (Table 1), SH-SY5Y cells were harvested, counted, and $10^{4}$ cells seeded onto each micro-PIXE sample holder. Cells were thereafter grown on polycarbonate films, differentiated with RA-TPA during 7 days and exposed to defined 
concentrations of natural uranium for 7 days more. Uranium exposure solutions at 10, 125 and 250 $\mu \mathrm{M}$ were selected according to the cytotoxicity assay results and prepared in complete cell growth medium by dilution of the $30 \mathrm{mM}$ intermediate uranium solution.

\begin{tabular}{|c|c|c|c|c|c|c|c|c|}
\hline & Cell culture & Seeding & & ifferer & ation & & nium expo & ure \\
\hline Day & -10 & 0 & 1 & 3.5 & 6 & 7 & 10.5 & 14 \\
\hline Task & $\begin{array}{l}\text { Thawing } \\
\text { and } \\
\text { standard } \\
\text { cell culture }\end{array}$ & $\begin{array}{l}\text { Seed cells } \\
\text { on poly- } \\
\text { carbonate } \\
\text { membrane }\end{array}$ & Add RA & $\begin{array}{l}\text { Add } \\
\text { TPA }\end{array}$ & $\begin{array}{c}\text { Prepare } \\
\text { uranium } \\
\text { intermediate } \\
\text { solution }\end{array}$ & $\begin{array}{c}\text { New medium } \\
\text { with } U\end{array}$ & $\begin{array}{c}\text { New } \\
\text { medium } \\
\text { with U }\end{array}$ & $\begin{array}{c}\text { Live cell } \\
\text { imaging and } \\
\text { cryo-fixation }\end{array}$ \\
\hline
\end{tabular}

Table 1. Protocol for SH-SY5Y cell culture, differentiation, and long-term exposure to natural uranium.

\subsection{Cytotoxicity studies}

The cytotoxic potential of uranium on differentiated SH-SY5Y cells was investigated by the CellTiterGlo ${ }^{\circledR}$ Luminescence Cell Viability Assay, an in vitro test that allows the measurement of the amount of intracellular ATP, which is directly linked to the number of metabolically active cells. Briefly, SHSY5Y cells were plated at the same density and conditions as described above. After differentiation, uranium toxicity was assessed between $0 \mu \mathrm{M}$ to $500 \mu \mathrm{M}$ and Triton $1 \%$ was used as a positive control. At the end of the exposure ( 7 days), The Promega CellTiter-Glo reagent was added and after a 20 min incubation, luminescence was measured on a luminescence plate reader (LumiStar, BMG) with a $5 \mathrm{~s}$ integrated reading. For each experimental point, four independent assays were carried out, each performed in sextuplate. Values were expressed as percentage of viability following the formula [(mean luminescence for a given sample condition/mean luminescence of unexposed cells)]. Data are presented as the mean \pm SD. The Prism6 software (GraphPad software; La Jolla, CA, USA) allowed to calculate IC50 values, as well as IC25 and IC75.

\subsection{Sample preparation for micro-PIXE experiments}

The protocol for sample preparation was adapted from recently optimized methods for element imaging in single cells using micro-PIXE (Perrin et al., 2015). At day 14 (Table 1), SH-SY5Y terminally differentiated cells were labeled with a fluorescent nuclear dye, Hoechst 33342, in order to perform correlative imaging of nucleus position in single cells with element distributions, as previously described (Roudeau et al., 2014). Live cell imaging of the nuclear dye fluorescence was recorded with an epifluorescence microscope (Olympus BX51). Immediately after live cell microscopy, cells were rinsed with a $150 \mathrm{mM}$ ammonium acetate buffer solution, $\mathrm{pH}$ 7.4, prepared in ultrapure water (Fisher) to remove traces of extracellular ions. Then cells were cryofixed by plunge freezing in isopentane chilled with liquid nitrogen down to $-160^{\circ} \mathrm{C}$, and freeze-dried at $-90^{\circ} \mathrm{C}$ under primary vacuum (Christ Alpha 1-4 freeze drier). After 3 days of freeze drying, samples were slowly brought back to room temperature and ambient pressure. Samples were stored into a dessicator dry box until analysis. 


\subsection{Micro-PIXE analyses and data treatment}

Micro-PIXE analyses were carried out at AIFIRA facility (Applications Interdisciplinaires des Faisceaux d'Ions en Région Aquitaine) (Sorieul et al., 2014). AIFIRA ion beam facility is based on a $3.5 \mathrm{MV}$ Singletron particle accelerator (HVEE, The Netherlands). The Singletron accelerator provided a 3.0 $\mathrm{MeV}$ proton beam that was focused down to $800 \mathrm{~nm}$ beam size using the high spatial resolution beamline resulting in a $0.5 \mathrm{nA}$ beam current. Uranium and the other chemical elements were mapped at the single cell level by performing micro-PIXE as recently reported (Ortega et al., 2014; Ortega et al., 2015). Single cells exposed to 0 (number of analyses, $n=8), 1 \mu M(n=5), 10 \mu M(n=18)$, $125 \mu \mathrm{M}(\mathrm{n}=26)$ and $250 \mu \mathrm{M}(\mathrm{n}=13)$ of uranium were analyzed. Quantification of element content in subcellular regions was obtained by extracting PIXE data from selected areas of the chemical maps (i.e. nucleus and cytoplasm). The exact location of the subcellular areas was defined thanks to the epifluorescence images evidencing the nucleus position in each cell following a correlative PIXE/epifluorescence microscopy approach (Roudeau et al., 2014). Calibration of the X-ray detectors was performed using Micromatter ${ }^{\mathrm{TM}}$ XRF calibration standards. Quantitative data treatment of PIXE spectra was performed using the GUPIXWIN software (Campbell et al., 2010). This software allows determining the element content and to precisely calculate detection limits. Charge normalization of PIXE data was obtained by performing simultaneously Rutherford Backscattering Spectrometry (RBS) following a methodology described in earlier publications (Carmona et al., 2008). The accuracy of the chemical elements quantification was checked by analyzing in the same conditions a $10 \mu \mathrm{m}$ section of the European Reference Material EC681k, as already described (Perrin et al., 2015). Due to the low intracellular concentrations of uranium, long acquisition times were required to map uranium distributions in single cells, from 4 hours to 12 hours per cell for the lower uranium exposure condition. In total the micro-PIXE analyses exceeded 500 hours of beam time.

\subsection{RNA Extraction and RT-qPCR}

Total RNA was isolated using the Qiagen RNeasy miniprep kit (Qiagen) according to the manufacturer's instructions. RNA concentration and purity were determined by OD measurement on a nanodrop 2000 spectrophotometer (Thermo Ficher Scientific). We obtained A260/A280 ratios in the range 1.9-2.1. $1 \mu \mathrm{g}$ of total RNA was retrotranscribed using the iScript ${ }^{\mathrm{TM}}$ Reverse Transcription Supermix for RT-qPCR (BIORAD) according manufacturer's instructions. Primers used for $\mathrm{qPCR}$ (BIORAD) are described in Table XX, the primer's efficiency was controlled by the supplier. The quantitative PCR was performed using SYBRgreen (Sso advanced universal SyBr Green supermix, Biorad, Hercules, CA) on a C1000 touch thermal cycler of Biorad (CFX96 Real Time System), according to the manufacturer's instructions, as follows: activation $2 \mathrm{~min}$ at $95^{\circ} \mathrm{C}, 40$ cycles of denaturation $(5 \mathrm{~s}$ at $\left.95^{\circ} \mathrm{C}\right), 40$ cycles of annealing $\left(30 \mathrm{~s}\right.$ at $\left.60^{\circ} \mathrm{C}\right)$. Melting curve analysis was performed for verifying specificity of each primer after $\mathrm{PCR}, 5 \mathrm{~s} / \mathrm{step}$ at $65^{\circ} \mathrm{C}-95^{\circ} \mathrm{C}\left(0.5^{\circ} \mathrm{C}\right.$ increments $)$, to ensure amplification specificity. Controls without template were included to verify that fluorescence was not overestimated from primer dimer formation or PCR contaminations. RT-qPCR products were analyzed in a post amplification fusion curve to ensure that a single amplicon was obtained. Normalization for RNA quantity, and reverse transcriptase efficiency was performed against two reference genes, glyceraldehyde 3- phosphate dehydrogenase (hGAPDH) and $\beta$ Actin (hACTB). For each experimental point, 3 independent assays were carried out, each performed in triplicate. Relative quantification was calculated using the $\Delta \Delta \mathrm{Ct}$ method which was normalized to the reference genes. All data were analyzed by the Bio-Rad CFX Manager 3.1 software. 


\section{Results and Discussion}

\subsection{Induction of a dopaminergic phenotype in $\mathrm{SH}-\mathrm{SY} 5 \mathrm{Y}$ cells}

Since uranium has potential toxicity to dopamine metabolism (Bussy 2006, Barber 2007, Briner 2008), we chose differentiated SH-SY5Y as a representative model of human dopamine neurons to study uranium-related neurotoxicity. The SH-SY5Y cell line is frequently used as in vitro model of dopaminergic neurons (Presgraves 2004, Kovalevich 2013, Westerink 2013), in particular for metalinduced neuronal toxicity studies (Stephenson 2013; Branca et al., 2018). However it is necessary to stimulate their differentiation using various agents, such as RA and TPA, into a more characteristically dopaminergic neuronal phenotype (Presgraves 2004, Barbosa 2014). However, culture conditions, cell source and differentiation protocol may vary. A recent review of the use of SH-SY5Y cells as a model for Parkinson's disease described the variability of these parameters in the published literature (Xicoy 2017). As indicated in this paper, several sources of SH-SY5Y are used. In our study, we compared two cell lines from (i) European Collection of Authenticated Cell Cultures (ECACC) and (ii) American Type Culture Collection (ATCC). The growing conditions recommended by the suppliers were strictly followed, and the calf serum recommended by ATCC was used exclusively for ATCC cells. The differentiation obtained after treatment with RA-TPA, gave satisfactory results in terms of neurite growth with the line from ATCC (Fig. 1) but not with that of EACC (data not shown). Consequently, we have selected ATCC cells for the continuation of our work. We also compared differentiation with RA alone (data not shown) or in combination with TPA (Fig. 1). Our results showed that only the combination of RA and TPA allowed to obtain an overexpression of TH, which confirms the results obtained by Presgraves (2004). After 7 days of differentiation, morphological and biochemical criteria were controlled (Fig. 1). Undifferentiated SH-SY5Y cells exhibited short neurites during the growth phase (Fig. 1A). After exposure to RA and TPA, an induction of extensive neurites outgrowth was observed (Fig. 1B). Tyrosine hydroxylase (TH) catalyzes the rate-limiting step in the synthesis of dopamine (DA) and other catecholamines, this makes TH the marker of choice for dopaminergic neurons. Therefore, change in $\mathrm{TH}$, was evaluated by western blot at the end of the differentiation process. A significant increase in the immunocontent of TH in differentiated cells was observed as compared to undifferentiated cells (representative western blot in Fig. 1C).

A

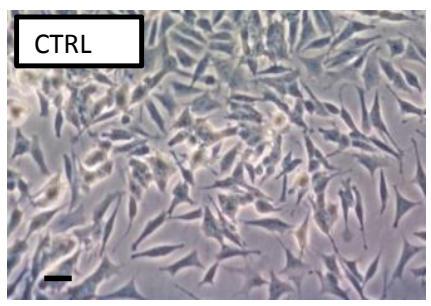

B

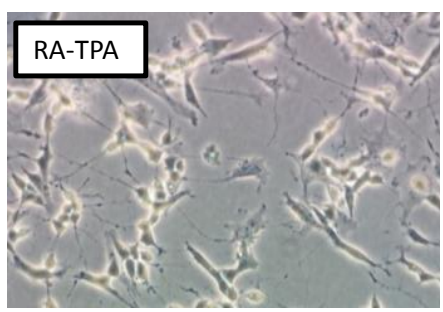

C

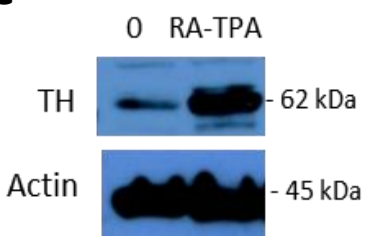

Figure 1. Induction of a dopaminergic phenotype in SH-SY5Y human cells verified by phase-contrast microscopy and western blot. (A) Undifferentiated control cells. Scale bar: $10 \mu \mathrm{m}$. (B) Differentiated cells showing neurite-like outgrowths after RA-TPA treatment. (C) Western blot analysis of tyrosine hydroxylase (TH) induction after RA-TPA treatment. Actin was used as loading control. 
Differentiated SH-SY5Y cells were exposed to increasing concentrations of natural uranium, from 0.1 to $1000 \mu \mathrm{M}$ in cell culture medium and cell viability was determined by measurement of ATP content (Fig. 2). Cell viability assays enabled to determine the uranium concentrations that will be further used to study uranium subcellular distribution. Three representative concentrations were selected as foolowing: a non-cytotoxic concentration $(10 \mu \mathrm{M})$, a concentration at the inflection point of the curve $(125 \mu \mathrm{M})$, representing the limit of observable cytotoxic effects, and a moderately toxic concentration inhibiting $15 \%$ of cell viability $(250 \mu \mathrm{M})$.

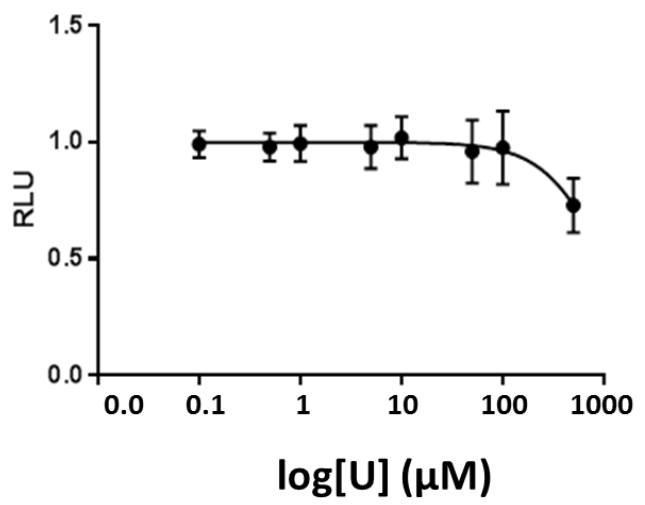

Figure 2. ATP cytotoxicity assay following long-term exposure of differentiated SH-SY5Y cells to natural uranium (RLU: relative luminescence units).

One of the main results of this study is that observable effects on cell viability after 7 days continuous exposure to natural uranium appears only at high uranium concentrations, greater than $100 \mu \mathrm{M}$. This result is in agreement with the relatively low cytotoxicity of uranium reported for various cell models. For example, in LLC-PK1 renal cells exposed for $24 \mathrm{~h}$ to uranium-bicarbonate, cytotoxic effects were observed only for concentrations greater than $700 \mu \mathrm{M}$ (Mirto et al., 1999). In NRK-52E normal renal tubular epithelial cells, the concentration leading to a $50 \%$ loss of viability was $450 \mu \mathrm{M}$ for $24 \mathrm{~h}$ exposure to uranium-bicarbonate (Carrière et al., 2004). Rouas et al. (2010) compared the cytotoxicity of depleted uranium on three human tumoral cell lines, HEK-293 kidney cells, Hep-G2 liver cells, and IMR-32 neuroblastoma cells, showing in all cases that cytotoxic effects appeared only for exposure concentrations greater than $300 \mu \mathrm{M}$ after either 24 or 48h. In UMR-106 osteosarcoma cells, a $50 \%$ loss of viability was observed after a $24 \mathrm{~h}$ exposure to $390 \mu \mathrm{M}$ of natural uranium bicarbonate (Pierrefite-Carle et al., 2016). These values have to be compared to the concentration of uranium in physiological fluids after normal exposure to uranium or after contamination. In normal individuals, uranium concentrations in the blood have been measured in the order of 5 to $10 \mathrm{ng} \cdot \mathrm{L}^{-1}$ ( 0.02 to $0.04 \mathrm{nM})$, and with values up to around $100 \mathrm{ng} \cdot \mathrm{L}^{-1}(0.4 \mathrm{nM})$ after occupational exposure (Byrne et al., 1991; Dang et al., 1993). These uranium concentrations measured in human blood are several orders of magnitude below the first observable effects on cell viability in vitro. However, the low cytotoxicity of natural uranium in vitro does not exclude more subtle effects on neurological functions. 


\subsection{Uranium subcellular distribution}

Micro-PIXE experiments were carried out on terminally differentiated SH-SY5Y cells after long-term exposure to natural uranium at $0,1,10,125$ and $250 \mu \mathrm{M}$. In control cells and cells exposed to $1 \mu \mathrm{M}$, uranium content was below the limit of detection of micro-PIXE of about $1 \mathrm{fg}$ per cell. Representative examples of intracellular uranium distribution for the other three exposure conditions are illustrated in Figures 3 to 5 . In total, 18 cells exposed to $10 \mu \mathrm{M}, 26$ cells exposed to $125 \mu \mathrm{M}$, and 13 cells exposed to $250 \mu \mathrm{M}$ were analyzed by micro-PIXE.

The micro-PIXE combined to epifluorescence correlative microscopy approach enabled to define precisely the intracellular distribution of uranium in the nucleus and cytoplasm areas, respectively. For all uranium exposure concentrations from 10 to $250 \mu \mathrm{M}$, uranium is localized in the cytoplasm (Figures 3 to 5), and never detected in the nucleus (Figure 6). Moreover, within the cytoplasm, uranium is not homogeneously distributed but rather accumulates in perinuclear sub-regions of the cytoplasm (Figure 3 to 5), probably within intracellular organelles. Single cell analysis also reveals that uranium levels are surprisingly variable from one cell to another one, as illustrated in figure 4 where the imaging of uranium in two adjacent cells shows a strong signal for the cell on the right of the image, and a much lower signal for the cell on the left. This inter-cellular variability is also exemplified by the large standard deviation found for the calculation of the mean uranium concentrations in single cells (Table 2). On the other hand, potassium is uniformly distributed within the whole cell as expected for this ubiquitous intracellular element (Figures 3 to 5). Potassium uniform distribution throughout the whole cell is a good marker of a correct preservation of native element distributions during sample preparation (Perrin et al., 2015). Potassium is present in cells as a highly diffusible ion, rendering its distribution very sensitive to osmotic changes during sample preparation that may remove it, together with other diffusible elements, out of the cells.

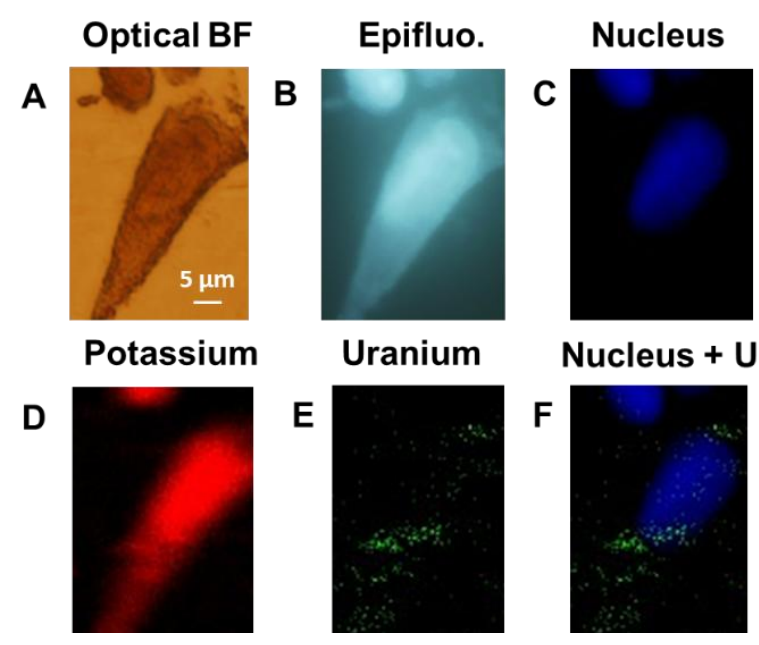

Figure 3. Optical and micro-PIXE imaging of a single SH-SY5Y cell after long-term exposure to $10 \mu \mathrm{M}$ uranium. (A) Bright field optical microscopy. (B) Epifluorescence optical microscopy of Hoechst 33542 nuclear dye. (C) Nucleus position derived from the epifluorescence image (false color, for overlay). 
(D) Potassium distribution. (E) Uranium distribution. (F) Overlay image of nucleus and uranium distribution.

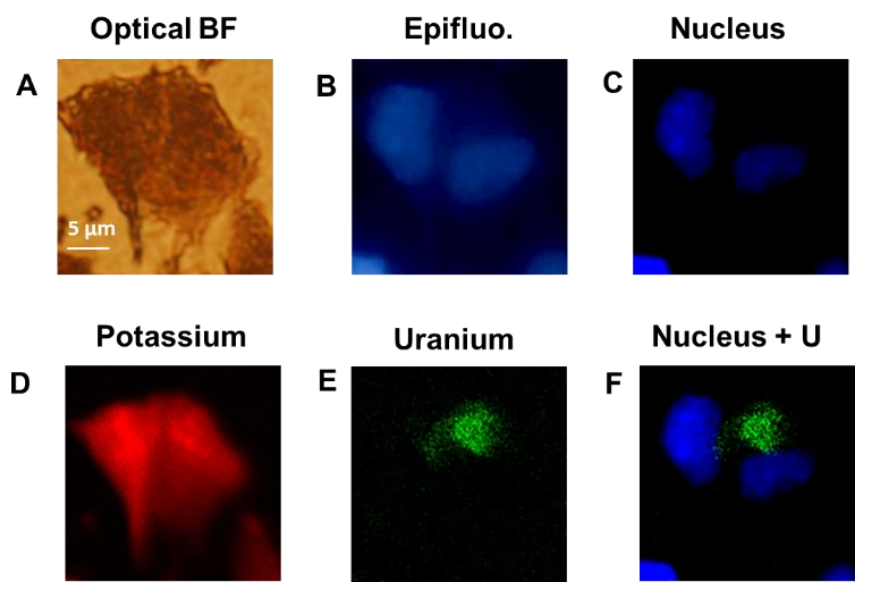

Figure 4. Optical and micro-PIXE imaging of single SH-SY5Y cells after long-term exposure to $125 \mu \mathrm{M}$ uranium. (A) Bright field optical microscopy. (B) Epifluorescence optical microscopy of Hoechst 33542 nuclear dye. (C) Nucleus position derived from the epifluorescence image (false color, for overlay). (D) Potassium distribution. (E) Uranium distribution. (F) Overlay image of nucleus and uranium distribution.

\section{Optical BF}

A

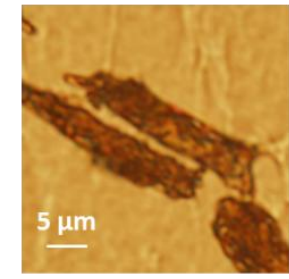

Potassium

D

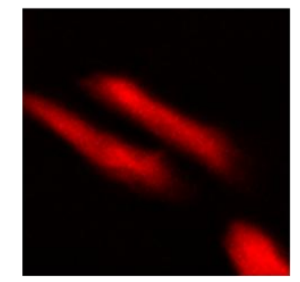

Epifluo.

B

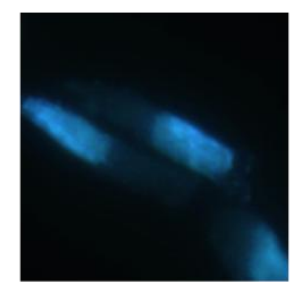

Uranium

$\mathbf{E}$

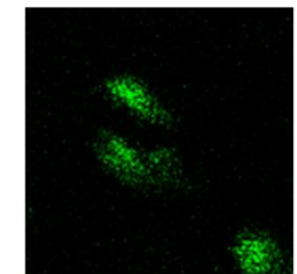

Nucleus

C

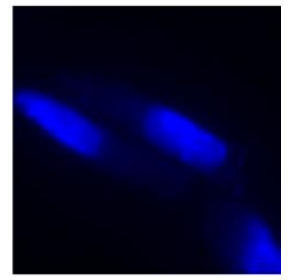

Nucleus $+U$

$\mathbf{F}$

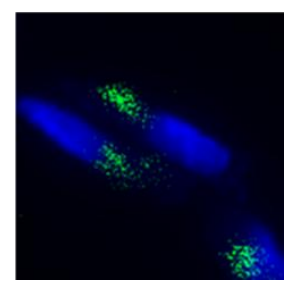

Figure 5. Optical and micro-PIXE imaging of single SH-SY5Y cells after long-term exposure to $250 \mu \mathrm{M}$ uranium. (A) Bright field optical microscopy. (B) Epifluorescence optical microscopy of Hoechst 33542 nuclear dye. (C) Nucleus position derived from the epifluorescence image (false color, for overlay). (D) Potassium distribution. (E) Uranium distribution. (F) Overlay image of nucleus and uranium distribution. 
A $10 \mu \mathrm{MU}$ exposure

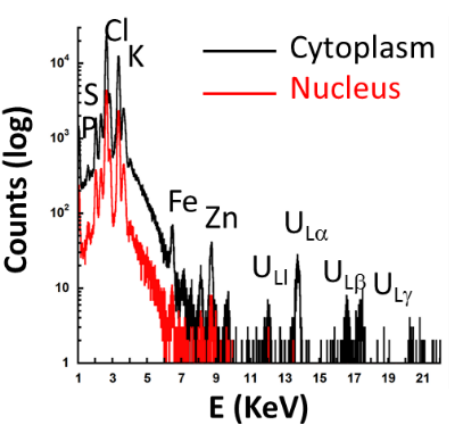

B $125 \mu \mathrm{M} \cup$ exposure

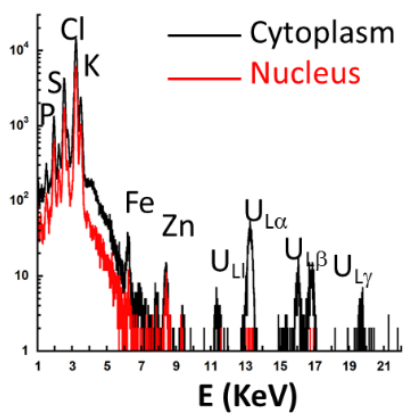

C $250 \mu \mathrm{MU}$ exposure

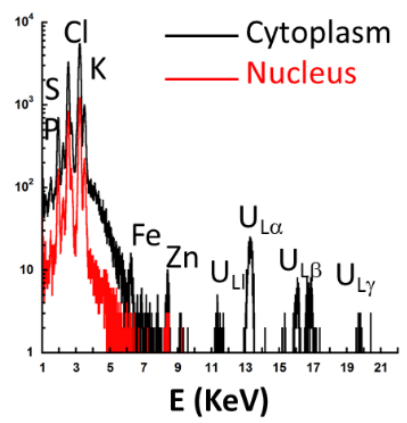

Figure 6. Examples of micro-PIXE spectra from sub-cellular areas, nucleus (black line) and cytoplasm (red line), extracted from single cells exposed to (A) $10 \mu \mathrm{M}$, (B) $125 \mu \mathrm{M}$, and (C) $250 \mu \mathrm{M}$ uranium. These spectra show that uranium is only detected within the cytoplasm, for the three exposure conditions.

Previous experiments using micro-analytical methods have also reported uranium distributions in singles cells. The first observations were carried out by transmission electron microscopy (TEM) since uranium can form electron-dense precipitates easily detected by TEM. This is the case for example in the study of NRK-52E kidney cells cultured with high uranium concentrations, uranium electron-rich structures were located either inside and outside the cells (Carrière et al., 2004 and 2008). Intracellular and extracellular uranium precipitates were also evidenced by TEM in UMR-106 osteosarcoma cells after $300 \mu \mathrm{M}$ uranium exposure, but not at lower concentration, such as $100 \mu \mathrm{M}$ (Pierrefite-Carle et al., 2015). In these cells, uranium precipitate was identified as meta-autunite using Extended X-ray Fine Structure Spectroscopy. Uranium precipitates were present in intracellular vesicles, such as lysosomes, multivesicular bodies or autophagosomes. In our study, we did not observe such intracellular precipitates probably because the exposure concentrations were below $300 \mu \mathrm{M}$ and the speciation of uranium in the extracellular medium was strictly controlled to avoid precipitation.

The imaging of intracellular soluble forms of uranium in cells requires micro-analytical methods with better sensitivity than TEM. The subcellular distribution of soluble uranium could be investigated owing to secondary ion mass spectrometry (SIMS) imaging. Soluble uranium was detected in the nucleus of HepG2 liver cancer cells after exposure to 10 and $50 \mu \mathrm{M}$, and in the nucleus of IMR32 neuroblastoma cells after exposure to $50 \mu \mathrm{M}$ depleted uranium nitrate (Rouas et al., 2010). These results were recently confirmed by the same research group, showing that in HepG2 cells uranium was rapidly incorporated into the nucleus (Guéguen et al., 2015). However, a very different subcellular distribution of uranium was described in renal cells from a rat model of uranium-induced acute renal toxicity as imaged using synchrotron radiation X-ray fluorescence (SRXRF) (HommaTakeda et al., 2015). In this latter study, uranium was present only in the cytoplasm of the renal cells, while it was found in the nucleus only for few necrotic cells. Our results are in good agreement with the subcellular distribution of uranium described in renal cells and imaged using SRXRF. In our study, we did not observe uranium in the nucleus of differentiated SH-SY5Y cells, but instead uranium was located only in the cytoplasm for all three exposure concentrations, 10, 125 and $250 \mu \mathrm{M}$. Such 
differences in uranium subcellular distribution might be explained by the denaturating conditions of sample preparation used for SIMS. For SIMS imaging, cells were chemically fixed with $2.5 \%$ glutaraldehyde, dehydrated in ethanol, and permeabilized with ethanol/epon mixture. Aldehyde fixation, alcohol dehydration and cell permeabilization are invasive methods known to drastically modify element distributions in cells, especially for soluble elements (Chjwiej et al., 2005; Matsuyama et al., 2009; Matysuyama et al., 2010; Hackett, et al., 2011; Roudeau et al., 2014; Perrin et al., 2015). Denaturating sample preparation conditions used for SIMS imaging can explain why uranium was not observed in the cytoplasm. For micro-PIXE imaging, and for SXRF imaging of renal tissue sections (Homma-Takeda et al., 2015), samples were processed using non denaturating conditions. In our study, cells were processed using cryogenic protocols consisting in fast cryofixation and controlled freeze-drying, a methodology validated to preserve the native distribution of the elements (Perrin et al., 2015).

Quantitative analysis of micro-PIXE data allowed to determine uranium content in single cells after exposure to the selected concentrations of natural uranium (Table 2). These results show that the intracellular content of uranium in the cytoplasm increased with the rise of the extracellular uranium concentration, but not proportionally. Intracellular uranium content was lower than the limit of detection $(<1 \mathrm{fg})$ in control cells that were cultured in control conditions, or exposed to $1 \mu \mathrm{M}$ of natural uranium. After long-term exposure to $10 \mu \mathrm{M}$, uranium is detected in cytoplasmic regions (34 $\pm 28 \mathrm{fg} / \mathrm{cell})$, and not in the nucleus area where uranium content is below the limit of detection $(<1$ $\mathrm{fg})$. After long-term exposure to $125 \mu \mathrm{M}$, uranium content increases considerably in the cytoplasm $(1297 \pm 1523 \mathrm{fg} / \mathrm{cell})$, with a 38 fold rise of the cytoplasmic content consequently to the exposure to extracellular uranium concentration 12.5 times higher(from $10 \mu \mathrm{M}$ to $125 \mu \mathrm{M}$ ). Then after long-term exposure to $250 \mu \mathrm{M} \mathrm{U}$, a 1.5 fold rise of uranium intracellular content is measured (1908 \pm 1207 $\mathrm{fg} /$ cell) compared to the $125 \mu \mathrm{M} \mathrm{U}$ exposure, roughly proportional to the increase of extracellular content by a factor two Our .... These results suggest a two-steps uptake of uranium. At $10 \mu \mathrm{M}$ uranium exposure, a non cytotoxic concentration (Fig. 2), the intracellular uranium content is very low. This result reflects a correct function of cellular mechanisms of defense through restrained uptake, efficient efflux, or both mechanisms. At higher exposure concentrations, the cellular mechanisms responsible for uranium uptake seem to be overwhelmed, resulting in much higher intracellular content. This two-steps behavior for uranium intracellular accumulation, after low or high exposure conditions, can be attributed to the activation of different uptake pathways as also suggested for intracellular uranium isotopic fractionation studies (Paredes et al., 2016).

Another striking result of the quantitative analysis of the data is the high inter-cellular variability of uranium content, as illustrated by the large standard deviation of the mean observed for all three exposure conditions (Table 2). This observation is very well illustrated by the very different uranium contents in two adjacent cells from the same sample (Fig. 4). These results seem to be rather unexpected considering that SH-SY5Y cells were fully differentiated and should therefore represent a quite uniform population in terms of protein expression profile. Also, since cells were exposed to uranium for a long period of time, 7 days, one could expect that all the cells would reach a stable and comparable intracellular uranium content. One explanation of these heterogeneous contents could be that the differentiation protocol led to heterogeneous phenotypes at the single cell level, although when measuring the average effect of differentiation it results in the expression of the 
dopaminergic phenotype. This variability has probably multiple origins that are difficult to explain with our data, however, identifying these origins would bring valuable information to understand the molecular mechanisms involved in the modulation of cell susceptibility to uranium uptake and toxicity.

\begin{tabular}{|c|c|}
\hline $\begin{array}{c}\text { U exposure } \\
(\boldsymbol{\mu M})\end{array}$ & $\begin{array}{c}\text { U content in the cytoplasm / cell } \\
(\mathrm{fg} \pm \text { SD) }\end{array}$ \\
\hline 0 & $<\operatorname{LOD}(\mathrm{n}=8)$ \\
\hline 1 & $<\operatorname{LOD}(\mathrm{n}=5)$ \\
\hline 10 & $34 \pm 28(\mathrm{n}=18)$ \\
\hline 125 & $1297 \pm 1523(\mathrm{n}=26)$ \\
\hline 250 & $1908 \pm 1207(\mathrm{n}=13)$ \\
\hline
\end{tabular}

Table 2. Uranium content in the cytoplasmic area of single differentiated SH-SY5Y cells after longterm exposure to 10,125 , and $250 \mu \mathrm{M}$ of natural uranium (LOD: limit of detection $=1 \mathrm{fg}$ ).

\subsection{Modulation of genes related to neurological functions after uranium exposure}

Using real-time quantitative RT-PCR analysis, the expression of genes related to catecholaminergic pathways was studied in uranium-treated SH-SY5Y cells and compared with unexposed cells (Table 3). Treatment with 10, 125 or $250 \mu \mathrm{M}$ uranium significantly decreased the expression of Monoamine Oxidase $B(\mathrm{MAOB})$ gene in a dose-dependent manner $(\mathrm{P}<0.05)$, the fold changes being respectively 1.8, -4.1 and -5.1. Tyrosine hydroxylase (TH) gene expression was also decreased, although the difference was statistically significant only after $10 \mu \mathrm{M}$ exposure. VMAT2 vesicular monoamine transporter 2 (SLC18A2 / VMAT2), Dopa decarboxylase (DDC), and dopamine receptor D1 (DRD1) gene expression were not modified upon uranium exposure or not statistically significantly. The signals obtained for DAT dopamine transporter (SLC6A3) and dopamine receptor D3 (DRD3) were too low to be detected.

\begin{tabular}{|c|c|c|c|c|c|}
\hline Gene & Name & Function & $\begin{array}{c}U \\
10 \mu M\end{array}$ & $\begin{array}{c}U \\
125 \mu M\end{array}$ & $\begin{array}{c}U \\
250 \mu M\end{array}$ \\
\hline DDC & $\begin{array}{c}\text { Dopa } \\
\text { decarboxylase }\end{array}$ & $\begin{array}{c}\text { Biosynthesis of } \\
\text { dopamine }\end{array}$ & -1.2 & 1 & 1.4 \\
\hline DRD1 & $\begin{array}{c}\text { D1 subunit of } \\
\text { dopamine receptor }\end{array}$ & Dopamine receptor & -3.2 & 1.1 & -1.5 \\
\hline DRD3 & $\begin{array}{c}\text { D3 subunit of } \\
\text { dopamine receptor }\end{array}$ & Dopamine receptor & ND & ND & ND \\
\hline MAO-B & $\begin{array}{c}\text { Monoamine } \\
\text { oxidase B }\end{array}$ & $\begin{array}{l}\text { Catabolism of } \\
\text { monoamines }\end{array}$ & $-1.8^{*}$ & $-4.1 *$ & $-5.1^{*}$ \\
\hline $\begin{array}{l}\text { SLC18A2 / } \\
\text { VMAT2 }\end{array}$ & $\begin{array}{l}\text { VMAT2 Vesicular } \\
\text { Monoamine }\end{array}$ & $\begin{array}{l}\text { Transport of } \\
\text { monoamines }\end{array}$ & 1.3 & 1.4 & 1.4 \\
\hline
\end{tabular}




\begin{tabular}{|c|c|c|c|c|c|}
\hline & Transporter 2 & neurotransmitters & & & \\
\hline SLC6A3 / DAT & $\begin{array}{c}\text { DAT Dopamine } \\
\text { transporter }\end{array}$ & Dopamine transport & ND & ND & ND \\
\hline TH & $\begin{array}{c}\text { Tyrosine } \\
\text { hydroxylase }\end{array}$ & $\begin{array}{c}\text { Biosynthesis of } \\
\text { dopamine }\end{array}$ & $-3.7^{*}$ & -1.2 & -3.1 \\
\hline
\end{tabular}

Table 3. RT-Q-PCR analysis of genes involved in catecholaminergic pathways of differentiated SHSY$5 Y$ cells after 7 days continuous exposure to 10,125 and $250 \mu \mathrm{M}$ natural uranium. Gene expression was compared to the respective untreated control. The expression levels of the target gene were normalized to the expression level of ACTB (beta actin) and GAPDH (Glyceraldehyde-3-Phosphate Dehydrogenase). * P-value < 0.05; ND: not detected.

Animal studies have shown that exposure to uranium can affect neurotransmitter pathways, in particular the cholinergic and monoamine systems (Bussy et al., 2006; Barber et al., 2007; Briner et al., 2008; Bensoussan et al., 2009; Dinocourt et al., 2015). For instance, acetylcholinesterase activity and monoamine metabolism were found to be disturbed in male rat brains after long-term chronic exposure to uranyl nitrate in drinking water (Bussy et al., 2006). In this study, acetylcholinesterase activity was transitionally perturbed in the cerebellum after 6 months of exposure but was unaffected in the striatum, hippocampus and frontal cortex. More pronounced effects were observed on monomamine metabolism in this same study. After 1.5 months of uranium exposure, dopamine level increased in the hypothalamus but not in other brain regions such as the striatum. After 9 months of exposure, a significant decrease of DOPAC (3,4-dihydroxyphenylacetic acid) was observed in the striatum, while dopamine and other monoamines and dopamine metabolites were unchanged. Our results, showing a decrease of MAO-B gene expression in dopaminergic cells exposed to uranium (Table 3) could explain the reported decrease of DOPAC level in the striatum after uranium exposure in rats through drinking water. Since dopamine is transformed into its metabolite DOPAC through MAO catalyzed deamination, depletion of MAO-B expression could result in DOPAC decrease. Both studies point out the specific sensitivity of dopamine catabolism pathway to uranium exposure. The finding of a specific MAO-B alteration following exposure to uranium can also be compared to the ones described for other neurotoxic metals. For example, exposure to manganese chloride can induce the decrease in the expression of MAO in mitochondria from rat brains (Zhang et al., 2003). Lead is another neurotoxic metal known to cause the decrease in MAO levels in animal models (Jaya Prasanthi et al., 2005; Chand Basha et al., 2014). Deficit of MAO-B have been associated to a broad range of neurological disorders such as psychotic disorders, depression, alcoholism, impulsivity, and neurodegenerative diseases (Bortolato et al., 2011).

The reported results on brain dopamine content of animal models exposed to uranium are however variable (Bussy et al., 2006; Barber et al., 2007; Briner et al., 2008). As previously mentioned, dopamine levels were unchanged in all brain regions after chronic exposure to depleted uranium at 1.5, 6 and 9 months exposure (Bussy et al., 2006). In another study, striatal dopamine content was reduced by $30 \%$ three days after intramuscular injection of $1 \mathrm{mg} / \mathrm{kg}$ of uranyl acetate but returned to control levels after 7 days (Barber et al., 2007). This acute exposure to uranium through intramuscular injection did not modify DOPAC levels in the striatum. In a 2-week study in mice exposed to $6 \mathrm{mg} \mathrm{U} / \mathrm{kg} /$ day (depleted uranyl acetate), exposure to uranium significantly increased tyrosine and decreased 3,4-dihydroxyphenylalanine (DOPA), norepinephrine, and epinephrine; but 
had no significant effect on dopamine or homovanillic acid (Briner 2008). In our study, TH gene expression was statistically significantly reduced after 7 days exposure to $10 \mu \mathrm{M}$ uranium. Overall these results suggest that uranium exposure alters the dopaminergic system but with different outcomes, probably reflecting differences in exposure conditions and the complexity of the uranium interaction with the dopaminergic system.

\section{Conclusions}

It is known from the literature that uranium exposure results in uranium circulating in the blood which will reach the brain causing neurological impairments. However too few data have been published to evaluate the thresholds of exposure and observable neurological effects and the molecular mechanisms involved in uranium neurotoxicity. In this study we have shown that after7 day exposure to natural uranium of dopaminergic cells a low cytotoxicity was observed. Toxic concentrations were greater than $100 \mu \mathrm{M}$, far from the expected uranium concentrations in blood even after occupational exposure $(<1 \mu \mathrm{M})$. The low uranium cytotoxicity can be explained by the limited cellular uptake of uranium, especially at low exposure concentration since this element was below the limit of detection ( $<1 \mathrm{fg}$ ) in cells exposed to $1 \mu \mathrm{M}$ uranium during 7 days, and detected in low content (34 fg / cell) after exposure to the non toxic concentration of $10 \mu \mathrm{M}$. The cytotoxicity effects only occurred for exposure concentrations higher than $100 \mu \mathrm{M}$ when uranium was detected in significant amount in cells ( $>1000 \mathrm{fg} /$ cell). Our results also suggest a differential cellular uptake of uranium after low or high uranium exposure. At low uranium exposure (1 and $10 \mu \mathrm{M})$, a very limited uranium incorporation is observed suggesting a controlled mechanism of uptake and efflux, while at high uranium exposure (100 and $250 \mu \mathrm{M})$ this controlled mechanism is less effective resulting in relatively high uranium intracellular concentrations. Another major result obtained in this study is that whatever the exposure concentration, up to $250 \mu \mathrm{M}$ during 7 days exposure, uranium was under the detection limit in the nucleus of differentiated SH-SY5Y cells suggesting that uranium toxicity is not induced by direct interaction with genomic DNA. Uranium was found only in the cytoplasm, restricted to perinuclear sub-regions suggesting organelle's confinement yet to be determined. This cytoplasmic perinuclear distribution of uranium might reflect interaction with the secretory pathway. An intriguing result of this study is the observed high inter-cellular variability with cells having not incorporated almost any uranium even at high exposure conditions during 7 days. Although this result is difficult to understand with the available data it highlights the importance of single cell analysis experiments. This intercellular variability in uranium uptake may reflect differences in cell differentiation at the single cell level, and/or other individual phenotypes which are critical in uranium uptake and subsequent toxicity. Although uranium was cytotoxic only at high concentrations (> $100 \mu \mathrm{M}$ ), some modifications of expression in genes involved in monoamine metabolism were detected after $10 \mu \mathrm{M}$ exposure. The main result was obtained for gene expression of monoamine oxidase $B$, being statistically significantly reduced after 10,125 and $250 \mu \mathrm{M}$ uranium exposure. This result might explain why DOPAC is decreased in rats chronically exposed to uranium in drinking water (Bussy et al., 2006). This last study and ours indicate that the catabolism of dopamine could be a critical target of uranium neurotoxicity. Further analyses are now required to better understand if low uranium exposure can interact with the secretory pathway in dopaminergic cells and with the monoamine oxidase protein expression. 


\section{Acknowledgements}

The authors gratefully acknowledge AIFIRA facility (Applications Interdisciplinaires des Faicseaux d'lons en Région Aquitaine) for beamtime allocation and for technical support. This work was funded by the Nuclear Toxicology program of CEA, the CNRS-IN2P3 Master Project IFI (Imagerie par Faisceau d'Ions), and the CNRS Interdisciplinary Mission through the PEPS (Projet Exploratoire Premier Soutien) Faidora program (Faibles Doses, Risques, Alertes).

\section{References}

Agency for Toxic Substances and Disease Registry (ATSDR). 2013. Toxicological profile for Uranium. Atlanta, GA: U.S. Department of Health and Human Services, Public Health Service.

Ansoborlo E, Lebaron-Jacobs L, Prat O. Uranium in drinking-water: a unique case of guideline value increases and discrepancies between chemical and radiochemical guidelines. Environ Int. 2015 Apr;77:1-4.

Barber DS, Hancock SK, McNally AM, Hinckley J, Binder E, Zimmerman K, Ehrich MF, Jortner BS. Neurological effects of acute uranium exposure with and without stress. Neurotoxicology. 2007 Nov;28(6):1110-9.

Bensoussan H, Grancolas L, Dhieux-Lestaevel B, Delissen O, Vacher CM, Dublineau I, Voisin P, Gourmelon $P$, Taouis $M$, Lestaevel P. Heavy metal uranium affects the brain cholinergic system in rat following sub-chronic and chronic exposure. Toxicology. 2009 Jun 30;261(1-2):59-67.

Bortolato M, Shih JC. Behavioral outcomes of monoamine oxidase deficiency: preclinical and clinical evidence. Int Rev Neurobiol. 2011;100:13-42.

Branca JJV, Morucci G, Maresca M, Tenci B, Cascella R, Paternostro F, Ghelardini C, Gulisano M, Di Cesare Mannelli L, Pacini A. Selenium and zinc: Two key players against cadmium-induced neuronal toxicity. Toxicol In Vitro. 2018 Apr;48:159-169.

Briner W. Effects of Depleted Uranium on Mouse Midbrain Catecholamines and Related Behavior. The Internet Journal of Toxicology. 2008 Volume 7 Number 1.

Bussy C, Lestaevel P, Dhieux B, Amourette C, Paquet F, Gourmelon P, Houpert P. Chronic ingestion of uranyl nitrate perturbs acetylcholinesterase activity and monoamine metabolism in male rat brain. Neurotoxicology. 2006 Mar;27(2):245-52

Byrne AR, Benedik L. Uranium content of blood, urine and hair of exposed and non-exposed persons determined by radiochemical neutron activation analysis, with emphasis on quality control. Sci Total Environ. 1991 Sep;107:143-57. 
Campbell J.L., Boyd N.I., Grassi N., Bonnick P., Maxwell J.A. (2010) The Guelph PIXE software package IV, Nucl. Instrum. Methods B, 268, 3356-3363,

Carmona A., Devès G., Ortega R. (2008) Quantitative micro-analysis of metal ions in subcellular compartments of cultured dopaminergic cells by combination of three ion beam techniques. Analytical Bioanalytical Chemistry, 390, 1585-1594.

Carrière M, Avoscan L, Collins R, Carrot F, Khodja H, Ansoborlo E, Gouget B. Influence of uranium speciation on normal rat kidney (NRK-52E) proximal cell cytotoxicity. Chem Res Toxicol. 2004 Mar;17(3):446-52.

Carrière M, Proux O, Milgram S, Thiebault C, Avoscan L, Barre N, Den Auwer C, Gouget B. Transmission electron microscopic and $\mathrm{X}$-ray absorption fine structure spectroscopic investigation of $U$ repartition and speciation after accumulation in renal cells. J Biol Inorg Chem. 2008 Jun;13(5):65562.

Chand Basha D, Saya Reddy N, Usha Rani M, Rajarami Reddy G. Age related changes in aminergic system and behavior following lead exposure: protection with essential metal supplements. Neurosci Res. 2014 Jan;78:81-9.

Chwiej J., Szczerbowska-Boruchowska M., Lankosz M., Wojcik S., Falkenberg G., Stegowski Z., Setkowicz Z. (2005)Preparation of tissue samples for. X-ray fluorescence microscopy, Spectrochim. Acta Part B 60, 1531-1537.

Dang, H. S., and Pullat, V. R. (1993) Normal concentration and excretion ratio of uranium in serum of normal individuals in India. Health Phys. 65, 303-315.

Dinocourt C, Legrand M, Dublineau I, Lestaevel P. The neurotoxicology of uranium. Toxicology. 2015 Nov 4;337:58-7

Guéguen Y, Suhard D, Poisson C, Manens L, Elie C, Landon G, Bouvier-Capely C, Rouas C, Benderitter $M$, Tessier $C$. Low-concentration uranium enters the HepG2 cell nucleus rapidly and induces cell stress response. Toxicol In Vitro. 2015 Dec 25;30(1 Pt B):552-60.

Frisbie S.H., Mitchell E.J., Mastera L.J., Maynard D.M., Zaki Yusuf A., Yusuf Siddiq M., Ortega R., Dunn R.K., Westerman D.S., Bacquart T., Sarkar B. (2009) Public health strategies for Western Bangladesh that address the arsenic, manganese, uranium and other toxic elements in their drinking water. Environmental Health Perspectives, 117, 410-416.

Frisbie SH, Mitchell EJ, Sarkar B. (2013) World Health Organization increases its drinking-water guideline for uranium. Environ Sci Process Impacts. 15(10):1817-23.

Hackett MJ, McQuillan JA, El-Assaad F, Aitken JB, Levina A, Cohen DD, Siegele R, Carter EA, Grau GE, Hunt NH, Lay PA (2011) Chemical alterations to murine brain tissue induced by formalin fixation: implications for biospectroscopic imaging and mapping studies of disease pathogenesis. Analyst 136(14):2941-2952.

Homma-Takeda S, Kitahara K, Suzuki K, Blyth BJ, Suya N, Konishi T, Terada Y, Shimada Y. Cellular localization of uranium in the renal proximal tubules during acute renal uranium toxicity. J Appl Toxicol. 2015 Dec;35(12):1594-600. 
Jaya Prasanthi RP, Hariprasad Reddy G, Bhuvaneswari Devi C, Rajarami Reddy G. Zinc and calcium reduce lead induced perturbations in the aminergic system of developing brain. Biometals. 2005 Dec;18(6):615-26.

Keith SL, Faroon OM, Fowler BA. (2008) Uranium. In: Handbook of the Toxicology of Metals. pp. 881904.

Kovalevich J, Langford D. Considerations for the use of SH-SY5Y neuroblastoma cells in neurobiology. Methods Mol Biol. 2013; 1078:9-21.

Matsuyama S, Shimura M, Mimura H, Fujii M, Yumoto H, Sano Y, Yabashi M, Nishino Y, Tamasaku K, Ishikawad T, Yamauchie K (2009) Trace element mapping of a single cell using a hard $\mathrm{x}$-ray nanobeam focused by a Kirkpatrick-Baez mirror system. X-Ray Spectrom 38:89-94

Matsuyama S, Shimura M, Fujii M, Maeshima K, Yumoto H, Mimura H, Sano Y, Yabashi M, Nishino Y, Tamasaku K, Ishizaka Y, Ishikawae T, Yamauchia K (2010) Elemental mapping of frozen hydrated cellswith cryo-scanning X-ray fluorescence microscopy. X-Ray Spectrom 39:260-266.

Mirto H, Hengé-Napoli MH, Gibert R, Ansoborlo E, Fournier M, Cambar J.Intracellular behaviour of uranium(VI) on renal epithelial cell in culture (LLC-PK1): influence of uranium speciation. Toxicol Lett. 1999 Feb 22;104(3):249-56.

Paredes E., Avazeri E., Malard V., Vidaud C., Reiller P., Ortega R., Nonell A., Isnard H., Chartier F., Bresson C. (2016) Evidence of isotopic fractionation of natural uranium in cultured human cells. Proc. Natl. Acad. Sci. USA., 113, 14007-14012.

Perrin L., Carmona A., Roudeau S., Ortega R. (2015) Evaluation of sample preparation methods for single cell quantitative element imaging using proton or synchrotron radiation focused beams. Journal of Analytical Atomic Spectrometry, 30, 2525-2532.

Pierrefite-Carle V, Santucci-Darmanin S, Breuil V, Gritsaenko T, Vidaud C, Creff G, Solari PL, Pagnotta $S$, Al-Sahlanee R, Auwer CD, Carle GF. Effect of natural uranium on the UMR-106 osteoblastic cell line: impairment of the autophagic process as an underlying mechanism of uranium toxicity. Arch Toxicol. 2017 Apr;91(4):1903-1914.

Presgraves SP, Ahmed T, Borwege S, Joyce JN. Terminally differentiated SH-SY5Y cells provide a model system for studying neuroprotective effects of dopamine agonists. Neurotox Res. 2004;5(8):579-98.

Ortega R., Bresson C., Darolles C., Gautier C., Roudeau S., Perrin L., Janin M., Floriani M., Aloin V., Carmona A., Malard V. (2014) Low-solubility particles and a Trojan-horse type mechanism of toxicity: the case of cobalt oxide on human lung cells, Particle \& Fibre Toxicology, 11:14.

Ortega R., Carmona A., Roudeau S., Perrin L., Dučić T., Carboni E., Bohic S., Cloetens P., Lingor P. (2016) Alpha-synuclein over-expression induces increased iron accumulation and redistribution in iron-exposed neurons. Molecular Neurobiology, 53, 1925-1934.

Rouas C, Bensoussan H, Suhard D, Tessier C, Grandcolas L, Rebiere F, Dublineau I, Taouis M, Pallardy $M$, Lestaevel $P$, Gueguen Y. Distribution of soluble uranium in the nuclear cell compartment at subtoxic concentrations. Chem Res Toxicol. 2010 Dec 20;23(12):1883-9. doi: 10.1021/tx100168c. 
Roudeau S., Carmona A., Perrin L., Ortega R. (2014) Correlative organelle fluorescence microscopy and synchrotron X-ray chemical element imaging in single cells. Analytical and Bioanalytical Chemistry, 406, 6979-6991.

Sorieul S., Alfaurt P., Daudin L., Serani L., Moretto P. (2014) Aifira: An ion beam facility for multidisciplinary research. Nucl. Instrum. Meth. B, 332, 68-73.

Stephenson AP, Schneider JA, Nelson BC, Atha DH, Jain A, Soliman KF, Aschner M, Mazzio E, Renee Reams R. Manganese-induced oxidative DNA damage in neuronal SH-SY5Y cells: attenuation of thymine base lesions by glutathione and N-acetylcysteine. Toxicol Lett. 2013 Apr 26;218(3):299-307.

Westerink RH. Do we really want to REACH out to in vitro? Neurotoxicology. 2013 Dec;39:169-72.

WHO, Guidelines for Drinking-water Quality, WHO, Geneva, 4th edn, 2011, pp. 1, 430-431, 475.

Zhang S, Zhou Z, Fu J. Effect of manganese chloride exposure on liver and brain mitochondria function in rats. Environ Res. 2003 Oct;93(2):149-57.

À citer

Paredes E., Avazeri E., Malard V., Vidaud C., Ortega R., Nonell A., Isnard H., Chartier F., Bresson C. A new procedure for high precision isotope ratio determinations of $\mathrm{U}, \mathrm{Cu}$ and $\mathrm{Zn}$ at nanogram levels in cultured human cells: what are the limiting factors? (2017), Talanta, 178, 894-904.

Vidaud C, Dedieu A, Basset C, Plantevin S, Dany I, Pible O, Quéméneur E. Screening of human serum proteins for uranium binding. Chem Res Toxicol. 2005 Jun;18(6):946-53. 